Bangl. J. Vet. Med. (2010). 8(2): $131-140$

\title{
CLINICAL AND LABORATORY DIAGNOSES OF NEWCASTLE AND INFECTIOUS BURSAL DISEASES OF CHICKENS
}

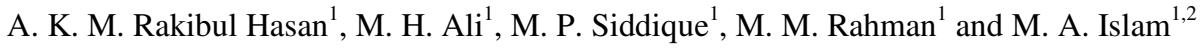 \\ ${ }^{1}$ Department of Microbiology and Hygiene, Faculty of Veterinary Science, Bangladesh Agricultural University, \\ Mymensingh-2202, and ${ }^{2}$ School of Sustainable Agriculture, University Malaysia Sabah, 88999, \\ Kota Kinabalu, Sabah, Malaysia
}

\begin{abstract}
A comparative study was conducted to compare the disease diagnostic parameters (clinical signs \& postmortem findings, organism isolation, serological test and molecular method) used to diagnose the Newcastle disease (ND) and infectious bursal disease (IBD) during the period from March 2009 to February 2010 in the laboratory of the Department of Microbiology and Hygiene, Bangladesh Agricultural University (BAU), Mymensingh. A total of 187 sick and dead chickens (63 broilers and 124 layers) of different ages ( 1 week to $>15$ weeks) were collected from 12 selective poultry farms ( 4 broilers and 8 layers) of Mymensingh and Gazipur districts. Clinically, 7 (14.89\%) of 63 affected broiler and 27 (30.68\%) of 124 affected layer chickens were diagnosed as Newcastle disease (ND) whereas, $11(23.4 \%)$ of 63 affected broiler and $6(4.82 \%)$ of the 124 affected layer birds were diagnosed as IBD on the basis of clinical history, clinical signs and postmortem findings. Virus isolation from field samples was performed by inoculating each suspected sample into 10-day-old chicken embryos. Out of 34 ND suspected field samples, 26 (5 broilers and 21 layers) were positive for NDV isolation and 11 (8 broilers and 3 layers) of 17 IBD suspected field samples, were positive for IBDV isolation. For confirmatory diagnosis, virus detection was confirmed by serological tests (HI and AGID) and RT-PCR assay. Out of 34 clinically diagnosed ND field samples, 20 (5 broiler \& 15 layer) were positive by RT-PCR assay and 15 (10 broiler \& 5 layer) of 17 IBD suspected field samples, were positive by both AGIDT and RT-PCR assay. Of the $26 \mathrm{HA}$ positive NDV suspected AF, 19 (4 broilers and 15 layers) were positive by both HI \& RT-PCR assay whereas, 10 (7 broilers and 3 layers) of 11 IBDV isolation positive tissue suspension were positive by both AGIDT \& RT-PCR assay in the laboratory. Therefore, it may be concluded that serological (HI \& AGIDT) and molecular (RT-PCR) techniques which allow rapid identification of most of samples are the reliable, sensitive, specific and more accurate methods to detect the viruses for the confirmatory diagnosis of diseases.
\end{abstract}

Key words: Clinical diagnosis, NDV, IBDV, HI, AGIDT, RT-PCR assay

\section{INTRODUCTION}

Newcastle disease (ND) is a highly contagious viral disease affects over 250 species of birds of all age groups (Alexander, 1997) and it is caused by Newcastle disease virus (NDV) a linear, non-segmented single stranded, enveloped, negative sense RNA virus belonging to the genus Rubula virus of sub-family Paramyxovirinae and family Paramyxoviridae (Barbezange and Jestin, 2005). NDV differs in virulence and has been grouped into 5 pathotypes: viscerotropic velogenic, neurotropic velogenic, mesogenic, lentogenic and asymptomatic enteric (Beard and Hanson, 1984). In Bangladesh, ND is mostly caused by velogenic strains of NDV than mesogenic or lentogenic strains. The disease produced by mesogenic strains may cause mortality that can reach $25 \%$ whereas, those by in velogenic strains maybe reach up to $100 \%$ and it varies from 80-90\% in the adults (Eisa and Omer, 1984 and Claudia et al., 1996). The major clinical signs of ND are depression, weakness, loss of appetite, dehydration, inability to stand, cyanosis of comb and wattle, greenish watery diarrhoea, nasal and eye discharges, decreased egg production, loss of weight followed by death (Pazhanivel et al., 2002). Gross lesions are petechial hemorrhages and ulcers with raised borders on the mucosa of proventriculus, pneumonic lungs, and hemorrhages in trachea, air sacs, brain and spleen (Pazhanivel et al., 2002).

Infectious bursal disease (IBD) is a highly contagious acute viral disease of young chickens of 3-6 weeks old that causes a fatality or immunosuppression by damaging bursa of Fabricius and impaired growth of young chickens which results significant economic losses in the poultry industry (Lukert and Saif, 1997 and Islam et al., 2005). The causal agent of IBD is infectious bursal disease virus (IBDV), a non-enveloped double stranded RNA

*Corresponding author: e-mail: alim_bau@yahoo.co.in 


\section{A. K. M. Rakibul Hasan}

(dsRNA) virus belonging to the family Birnaviridae (Jackwood et al., 1984). IBDV strains have been classified into two distinct serotypes 1, pathogenic and 2, non-pathogenic (Ismail et al., 1988 and Van den Berg, 2000). The disease is manifested by debilitaty, dehydration and the development of depression with watery diarrhea, swollen and blood stained vent (Islam and Samad, 2004a). Severity of the signs depends on the virus strain and the age and breed of the chickens (Van den Berg et al., 1991a). Infection with less virulent strains may not show obvious clinical signs but the birds may have fibrotic or cystic bursa of Fabricius that become atrophied prematurely (before six months of age) and may die of infections by agents that would not usually cause disease in immunocompetent birds (The Merck Veterinary Manual. 2006). The postmortem findings were hemorrhages in the thigh/pectoral muscles, enlarged, edematous and hyperemic bursa or atrophic in chronic cases and hemorrhage in the junction between gizzard and proventriculus (Chettele et al. 1989). Though gross lesions of IBD affected poultry are considered sufficient for diagnosis but sometimes confused with other diseases (Banda, 2002).

The detection and differentiation of NDV are based on virus isolation using embryonated chicken eggs, followed by an in vivo determination of pathogenicity in chickens, such as the intracerebral pathogenicity index (ICPI) in 1-day-old chicks, the intravenous pathogenicity index (IVPI) in 6-week-old chickens, or the mean death time (MDT) in chicken embryos (Alexander, 1988). However, these tests are labors intensive and time consuming (Aldous, et al. 2001). Various diagnostic methods like haemagglutination inhibition (HI) test, indirect haemagglutination (IHA) test, virus neutralization test (VNT), enzyme linked immunosorbent assay (ELISA), fluorescent antibody technique (FAT), plaque reduction neutralization test (PRNT) and agar gel immunodiffusion test (AGIDT) are used limitedly to detect NDV and IBDV. Molecular techniques like reverse transcriptase polymerase chain reaction (RT-PCR) have been frequently used all over the world to detect viruses from the field samples (Kant et al., 1997; Liu et al., 1998; Gohm et al., 2000 and Mathivanan et al., 2004).

Clinical manifestations and postmortem findings of affected birds may aid to diagnose a disease but laboratory diagnosis is necessary for confirmation of the diseases (Banda, 2002). In Bangladesh diagnosis of poultry diseases at field level is limited within recording of clinical history and signs and post-mortem findings where there is every chance of wrong diagnosis because the signs and post-mortem findings are more or less similar in most of the diseases.

Therefore, the present study was undertaken to find out a relationship among the disease diagnostic parameters, i.e; clinical signs and postmortem lesions, organism isolation, serological tests and molecular methods for the diagnosis of Newcastle and infectious bursal diseases.

\section{MATERIALS AND METHODS}

A comparative study between the clinical and laboratory diagnoses of Newcastle and infectious bursal diseases of poultry of Mymensingh and Gazipur districts was conducted during the period from March 2009 to February 2010 in the laboratory of the Department of Microbiology and Hygiene, Faculty of Veterinary Science, Bangladesh Agricultural University (BAU), Mymensingh-2202.

\section{Samples for the isolation of viruses}

A total of 187 (63 broiler and 124 layer) sick and dead chickens aged between 1 to $>15$ weeks were collected from 12 (4 broiler and 8 layer) farms, which were subjected for postmortem examination and collection of different tissue samples (trachea, lung, spleen, soft palate, colon, bursa and brain) for successful isolation and identification of viruses.

\section{Clinical diagnosis of viral diseases}

Clinical diagnosis was made on the basis of clinical history from the responsible persons of the farms, recorded clinical signs and gross lesions of affected chickens.

\section{Laboratory diagnosis of viral diseases \\ Reference viruses \\ NDV and IBDV: Velogenic strain of NDV and virulent strain of IBDV of the serotype 1 was used as reference viruses obtained from the Dept. of Microbiology and Hygiene, BAU, Mymensingh.}




\section{Preparation of hyper-immune serum}

Four 6 month-old non-vaccinated Fayoumi chickens were vaccinated using live NDV and IBDV vaccine at day $7^{\text {th }}, 14^{\text {th }}$ and $21^{\text {st }}$. Hyper-immune serum was separated from the blood collected from vaccinated chickens and preserved at $-20^{\circ} \mathrm{C}$ until further use.

\section{Isolation of NDV and IBDV in avian embryo}

The specific pathogen free viable 10 day-old embryonated chicken eggs were inoculated through allantoic cavity route for NDV and chorio-allantoic membrane (CAM) route for IBDV @ $0.2 \mathrm{ml}(0.1 \mathrm{ml}$ virus suspension $+0.1 \mathrm{ml}$ antibiotic mixture) of inoculums. The embryos died after $24 \mathrm{hrs}$ of incubation were chilled at $4{ }^{\circ} \mathrm{C}$ for $1-$ 2 hours. Allantoic fluid was collected and tested by slide HA test. Those manifesting HA-positive (clumping of RBC) were collected, as a source of ND virus. For IBDV samples dead embryo and CAM were homogenized with PBS to prepare $50 \%$ suspension and stored at $-80^{\circ} \mathrm{C}$ for further use.

\section{Serological Methods}

\section{Hemagglutination Inhibition (HI) test for the detection of NDV}

HA positive samples (AF) were subjected for HI test. A $25 \mu \mathrm{l}$ of PBS was taken to all wells (A1- H12) of each numbered column and $25 \mu \mathrm{l}$ of anti-NDV hyper-immune serum was added to the every first well (A12 was NDV control). Serial two fold dilution of sera was made and $25 \mu \mathrm{l}$ of control antigen was added to the well (A1-H1 and A2-H2) and test antigens were taken to the remaining wells. A volume of $25 \mu \mathrm{l}$ of PBS was added to serum control plate instead of antigen and kept for $60 \mathrm{~min}$ at room temperature. Then $50 \mu \mathrm{l}$ of $0.6 \% \mathrm{cRBC}$ was added to all wells and kept at room temperature at least for $25 \mathrm{~min}$ to record the result (Anon, 1971).

Agar gel immunodiffusion test (AGIDT) for the detection of IBDV

All the isolation positive field samples (50\% inocula) and tissue suspension (CAM \& embryo) were used for AGIDT. The test was performed according to the procedure described by Wood et al. (1979).

\section{Molecular method}

\section{Extraction of viral RNA}

The genomic viral RNA of the viruses was extracted from $140 \mu \mathrm{l}$ of IBDV and NDV suspected field samples (inocula), laboratory samples (CAM and embryo suspension for IBDV and AF for NDV) and reference viruses (IBDV \& NDV) using QIAamp viral RNA mini kit (QIAGEN, Hilden, Germany) according to the manufacturer's protocol. The RNA was extracted in $60 \mu \mathrm{l}$ of elution buffer and used as template directly for RTPCR assay or stored at $-80^{\circ} \mathrm{C}$ until further use.

\section{Selection of oligonucleotide primers}

Newcastle disease virus specific sense and complementary primer sets and infectious bursal disease virus type specific sense and complementary primers designed by using OLIGO 2 software (courtesy of Prof. Dr. K. Morita, Institute of Tropical Medicine, Nagasaki University, Japan) were used for RT-PCR.

Primers used for RT-PCR of IBDV and NDV

\begin{tabular}{c|c|c}
\hline Primers & Sequence (5'-3') & $\begin{array}{c}\text { Nucleotide } \\
\text { Position }\end{array}$ \\
\hline Vvfp 775 (Sense) & 5'-AATTCTCATCACAGTACCAAG -3' & $253 \mathrm{bp}$ \\
Vvrp 1028 (Antisense) & 5'-GCTGGTTGGAATCACAAT -3' & $387 \mathrm{bp}$ \\
\hline NDV/Fa (Sense) & 5'TCAACATATACACCTCATCCCAGACAGG-3' \\
\hline
\end{tabular}

\section{RT-PCR for the detection of ND and IBD viral genome} Synthesis of cDNA from RNA

A volume of $4 \mu \mathrm{l}$ of eluted RNA of NDV or IBDV and $8.3 \mu 1 \mathrm{dH} 2 \mathrm{O}$ were mixed properly and allowed for linearization of coiled RNA in thermocycler (MJ Mini thermocycler, BIORAD®, USA) maintaining $94^{\circ} \mathrm{C}$ temperatures for $5 \mathrm{~min}$ followed by $2 \mathrm{~min}$ snap cooling on ice to stay liberalized. Meanwhile, for the synthesis of cDNA from RNA of NDV or IBDV, reaction mixture 1 containing 5XRT buffer $4.0 \mu \mathrm{l}, 10 \mathrm{mM}$ dNTP $2.0 \mu \mathrm{l}$, prime RNase inhibitor $1.0 \mu \mathrm{l}$, AMV-RT $0.2 \mu \mathrm{l}$, primer (RH 100 pmol) $0.5 \mu \mathrm{l}$, Template RNA $4 \mu \mathrm{l}$, dH2O $8.3 \mu \mathrm{l}$ were prepared and kept on ice. After adding this reaction mixture on to the PCR tube containing linearized RNA of NDV or IBDV placed into the thermocycler and followed the thermal profile as $42^{\circ} \mathrm{C}$ for 40 min followed by $85^{\circ} \mathrm{C}$ for $5 \mathrm{~min}$. 


\section{A. K. M. Rakibul Hasan}

\section{Synthesis of DNA from cDNA of NDV}

For the synthesis of DNA from cDNA of NDV, reaction mixture- 2 were used as $50 \mu$ l volume containing $10 \mathrm{X}$ LA buffer $5.0 \mu \mathrm{l}, 25 \mathrm{mM} \mathrm{MgCl} 22.0 \mu \mathrm{l}, 10 \mathrm{mM}$ dNTP $2.0 \mu \mathrm{l}$, LA-Taq $0.2 \mu \mathrm{l}$, NDV/Fa primer $0.8 \mu \mathrm{l}$ and NDV/Ra primer $0.8 \mu \mathrm{l}$, cDNA $1.5 \mu \mathrm{l}$, and DEPC $37.7 \mu \mathrm{l}$ to each tube and mixed with minispin. The tubes were immediately placed to the thermocycler and maintained the thermal profile at $94^{\circ} \mathrm{C}$ for $2 \mathrm{~min}, 30$ cycles were continued at $94^{\circ} \mathrm{C}$ for 30 seconds for denaturation, $45^{\circ} \mathrm{C}$ for 45 seconds for annealing, $60^{\circ} \mathrm{C}$ for 1 min for elongation and final elongation at $60^{\circ} \mathrm{C}$ for $10 \mathrm{~min}$.

\section{Synthesis of DNA from cDNA of IBDV}

For the synthesis of DNA from cDNA of NDV, reaction mixture-2 were used as $50 \mu 1$ volume containing $10 \mathrm{X}$ LA buffer $5.0 \mu \mathrm{l}, 25 \mathrm{mM} \mathrm{MgCl} 22.0 \mu \mathrm{l}, 10 \mathrm{mM}$ dNTP $2.0 \mu \mathrm{l}$, LA-Taq $0.2 \mu \mathrm{l}$, Vvfp 775 primer $0.8 \mu \mathrm{l}$ and Vvrp 1028 primer $0.8 \mu \mathrm{l}$ (for IBDV), cDNA $1.5 \mu \mathrm{l}$, and DEPC $37.7 \mu \mathrm{l}$ to each tube and mixed with minispin. The tubes were immediately placed to the thermocycler and maintained the thermal profile at $94^{\circ} \mathrm{C}$ for $2 \mathrm{~min}, 30$ cycles were continued at $94^{\circ} \mathrm{C}$ for 30 seconds for denaturation, $45^{\circ} \mathrm{C}$ for 45 seconds for annealing, $60^{\circ} \mathrm{C}$ for 1 min for elongation and final elongation at $60^{\circ} \mathrm{C}$ for $10 \mathrm{~min}$.

\section{Agarose gel electrophoresis}

To confirm the target gene, $3 \mu 1$ of PCR product with $1 \mu 1$ of $6 \mathrm{X}$ gel loading dye was electrophoresed (Gel Mate 2000, Toyobo, Japan) on 2\% agarose gel containing ethidium bromide (1\% solution @ $5 \mu \mathrm{l} / 100 \mathrm{ml})$ at constant $90 \mathrm{~V}$ for $40-50$ minutes in $0.5 \mathrm{X}$ TBE buffer. A $5 \mu \mathrm{l}$ DNA size marker was loaded in one well. The amplified product was visualized under UV light and documented by gel documentation system.

\section{RESULTS AND DISCUSSION}

\section{Clinical diagnosis of diseases}

Newcastle disease (ND)

Clinically, 7 (14.89\%) birds of the 63 affected broiler chickens and 27 (30.68\%) of the 124 affected layer chickens were diagnosed as ND (Table 1). The most common clinical signs were edema of the head-face-wattles, twisted neck \& paralysis (Plate 1), greenish diarrhea, cessation of egg production, soft-shelled egg and death which were similar with the findings of Beach (1942), Banerjee et al. (1994) and Alexander (1997). Most commonly observed postmortem lesions were pin point hemorrhages at the tip of proventricular glands (Plate 34), hemorrhagic ulcers in intestinal wall and caecal tonsils, petechial hemorrhage in colon, hemorrhagic lungs, tracheitis (Plate 2) with congestion and catarrhal exudates. These findings agree with the findings of Kotani et al. (1987), Crespo et al. (1999), Talha et al. (1999) and Pazhanivel et al. (2002).

\section{Infectious bursal disease (IBD)}

A total of $11(23.4 \%)$ of the 63 affected broiler and $6(4.82 \%)$ of the 124 affected layer birds were diagnosed as IBD (Table 1) and observed clinical signs were high mortality, unsteady gait, ruffled feathers (Plate 5), uratecontaining diarrhea and sudden death which correspond with the findings of Lukert and Saif (2003), Islam and Samad (2004). The postmortem findings were hemorrhages in the thigh/pectoral muscles (Plate 6), enlarged, edematous and hyperemic bursa (Plate 7) with bloody or mucoid contents (Plate 8) or atrophic in chronic cases and hemorrhage in the junction between gizzard and proventriculus which support the findings of Chettele et al. (1989), Lukert \& Hitchner (1984) and Islam \& Samad (2004).

Table 1. Clinical diagnosis of Newcastle and infectious bursal disease suspected cases

\begin{tabular}{c|c|c|c|c|c|c|c|c}
\hline Name of the diseases & \multicolumn{2}{|c|}{$\begin{array}{c}\text { Total number of } \\
\text { study samples }\end{array}$} & \multicolumn{2}{c|}{ Clinically diagnosed } & \multicolumn{3}{c}{ Prevalence (\%) } \\
\cline { 2 - 10 } & Broiler & Layer & Broiler & Layer & Total & Broiler & Layer & Overall \\
\hline Newcastle disease & 63 & 124 & 7 & 27 & 34 & 14.89 & 30.68 & 53.96 \\
\hline $\begin{array}{c}\text { Infectious bursal } \\
\text { disease }\end{array}$ & 63 & 11 & 6 & 17 & 23.4 & 4.82 & 17.7 \\
\hline
\end{tabular}




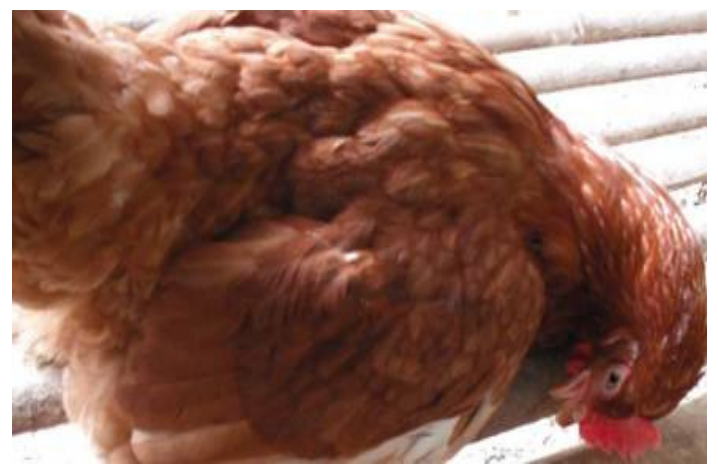

Plate 1. NDV infected layer chicken of 29 weeks of age showing nervous signs (twisted neck and paralysis)

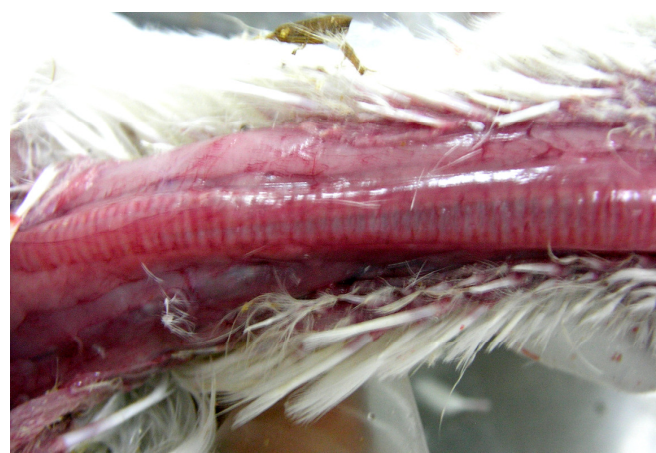

Plate 2. Chicken infected with NDV showing hemorrhages in the trachea chicken infected with
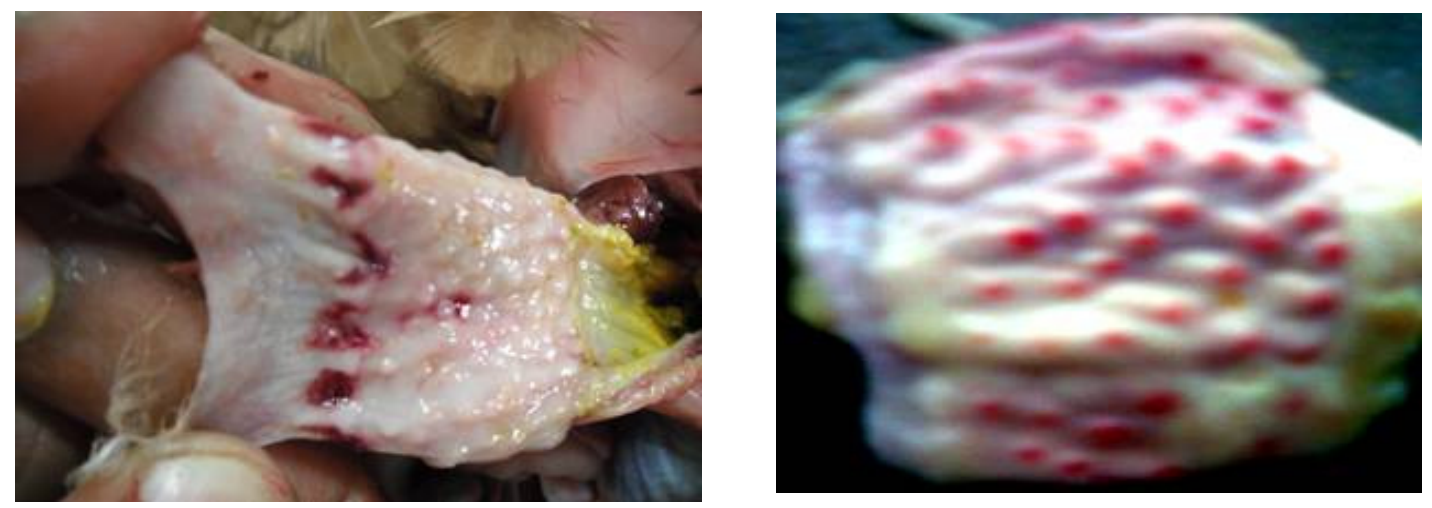

Plate 3-4. Presence of ulcer and pin point haemorrhages in the proventriculus of chickens affected with ND.

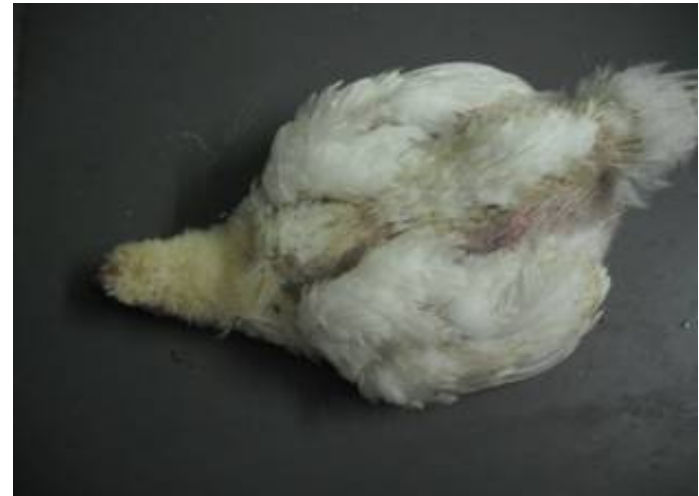

Plate 5. Broiler chicken of 20 days infected with IBDV showing depression and unsteady gait

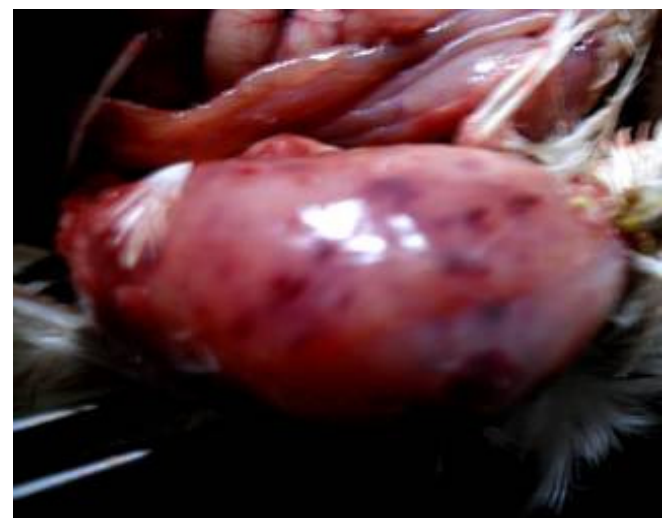

Plate 6. Broiler chicken of 24 days age affected with IBD showing hemorrhages in the thigh muscles 


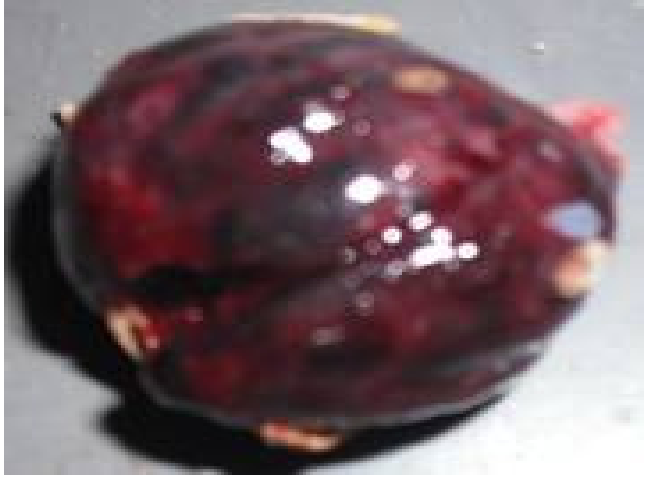

Plate 7. Swollen and hyperemic bursa of Fabricius of IBD affected broiler chicken

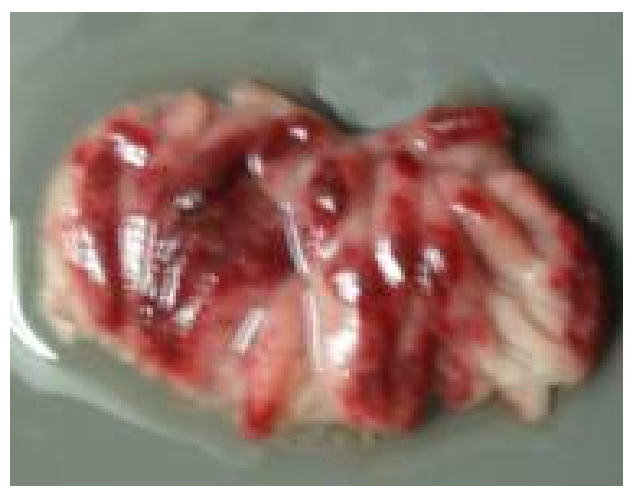

Plate 8. Cut section of bursa of IBDV infected broiler chickens showing bloody and mucoid contents

\section{Laboratory diagnosis \\ Isolation of NDV in chicken embryos}

A total of $26(76.47 \%)$ samples from 34 clinically diagnosed ND affected chickens, were positive for virus isolation in embryonated eggs (Table 2). In all positive cases embryos died within 24 to 96 hours of postinoculation (Spackman et al., 2003 and Woolock, 2008). All of the 26 AF samples showed positive rapid slide HA activity within few seconds which indicated that the isolates were hemagglutinating viruses (Okoye, 1983). The HA positive samples were subjected for the determination of virus titer which were within a range of 64512.

\section{Isolation of IBDV in chicken embryos}

Out of the 17 clinically diagnosed IBD affected samples, 11 (64\%) were positive for isolation of virus which were negative to rapid slide HA test (Table 2). In positive cases the embryos were died within 24 to 96 hours of post-inoculation. The CAM was thickened, dead embryos were congested and hemorrhagic (petechial and ecchymotic) along the feather tracts, toe and cerebral area which were similar to the findings of Hitchner (1970) and Takase et al. (1996). The reduced rate of virus isolation may be due to absence or low concentration of virus in the remaining six inoculums or due to the presence of maternal antibody in the embryonated eggs (Rosales $e t$ al., 1989).

Table 2. Results of virus isolation using embryonated chicken embryos

\begin{tabular}{c|c|c|c|c|c|c|c}
\hline Name of the Diseases & \multicolumn{3}{|c|}{ Samples inoculated } & \multicolumn{4}{|c}{ Virus isolation positive } \\
\cline { 5 - 8 } & \multirow{2}{*}{ Broiler } & Layer & \multirow{2}{*}{ Total } & \multirow{2}{*}{ Broiler } & Layer & No. & $\%$ \\
\hline ND & 7 & 27 & 34 & 5 & 21 & 26 & $76.47 \%$ \\
\hline IBD & 11 & 6 & 17 & 8 & 3 & 11 & $64 \%$ \\
\hline
\end{tabular}

\section{Hemagglutination inhibition test using hyper-immune serum against NDV}

Out of the 26 HA positive AF, 19 (73.08\%) were neutralized by anti-NDV hyper-immune serum whereas, 7 were not neutralized which indicated these were other than NDV (Table 3). The result of this study partially agrees with the findings of Alders et al. (1994), Manin et al., (2002) and Singh et al. (2005) who successfully detected and differentiated NDV from the field samples by HI test using NDV specific polyclonal serum.

\section{AGID test using hyper-immune serum against IBDV}

Prominent white line of precipitation was noticed between known positive anti-IBDV hyper-immune serum of the central well and bursal homogenates of the peripheral wells due to antigen and antibody reaction within 24$48 \mathrm{hr}$. By AGIDT, out of 17 field samples, 15 (10 broiler and 5 layer) samples and of the 11 laboratory samples, 10 (7 broiler and 3 layer) samples were positive for IBDV (Table 3). The results are in agreement with the findings of Karunakaran et al. (1993), Muhammad et al. (1996), Gupta et al. (2001). No line of precipitation was observed in $2(8.57 \%)$ field samples and one tissue suspension that were considered as negative for IBDV antigen. 


\section{RT-PCR for Newcastle disease virus (NDV)}

The nucleic acid based detection tests like RT-PCR have been used for the detection of viruses (Liu et al., 1994 and Kataria et al., 2000). Viral RNA was extracted from both 34 field samples and 26 HA positive AF for the detection of NDV genome by RT-PCR using NDV specific primers. Out of 34 field samples, 26 (5 broilers and 21 layers) samples and of the 26 (5 broilers and 21 layers) AF, 19 (4 broilers and 15 layers) samples were positive for the detection of NDV viral genome (Table 3). This low rate of detection may be due to presence of hemagglutinating viruses other than NDV in the AF. A clear and distinct band of RT-PCR product was appeared at the position of $387 \mathrm{bp}$ with the standard $100 \mathrm{bp}$ DNA ladder passed through $2 \%$ Agarose gel electrophoresis (Plate 9). The results almost similar with the findings of Kant et al. (1997), Nanthakumar et al. (2000), Gohm et al. (2000) and Singh et al. (2005).

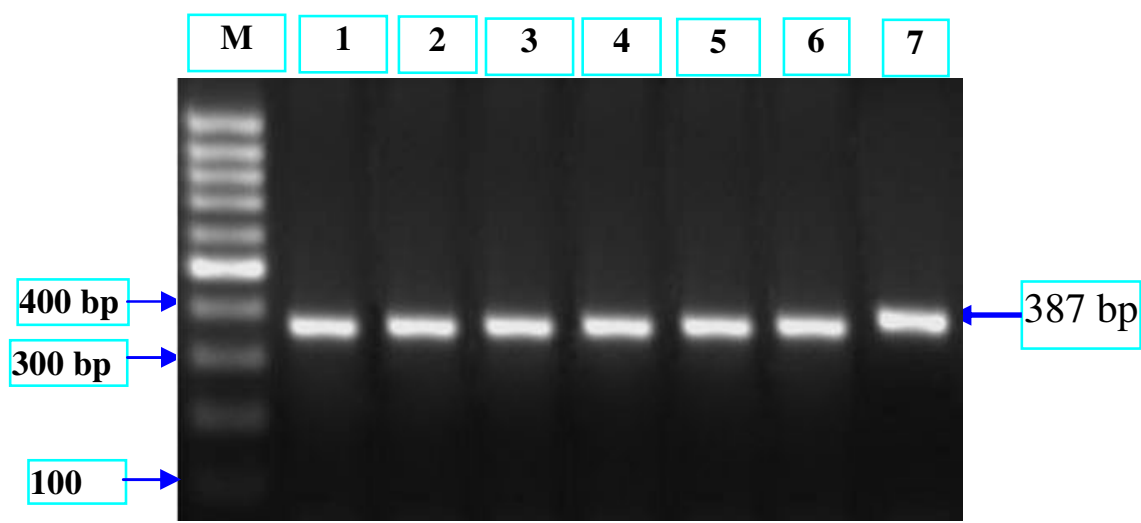

Plate 9. RT-PCR products of NDV (387 bp) from field samples showing specific bands on $2 \%$ agarose gel electrophoresis. $\mathrm{M}=100$ bp DNA Marker, Lane 1= reference NDV and Lane 2-7 = field samples

\section{RT-PCR for infectious bursal disease (IBDV)}

Extracted RNA of all 17 field samples and 11 laboratory samples were amplified by RT-PCR using IBD virus specific primers. Of the 17 field samples, 15 (10 broiler and 5 layer) and of the 11 laboratory samples, 10 (7 broiler and 3 layer) were found to be positive for IBD viral genome (Table 3). The RT-PCR products were found as a clear and distinct band at $253 \mathrm{bp}$ with the standard $100 \mathrm{bp}$ DNA ladder passing through $2 \%$ Agarose gel electrophoresis (Plate 10). This study results partially agreed with the findings of Lee et al. (1994), Banda et al. (2001) and Hernandez et al. (2006).

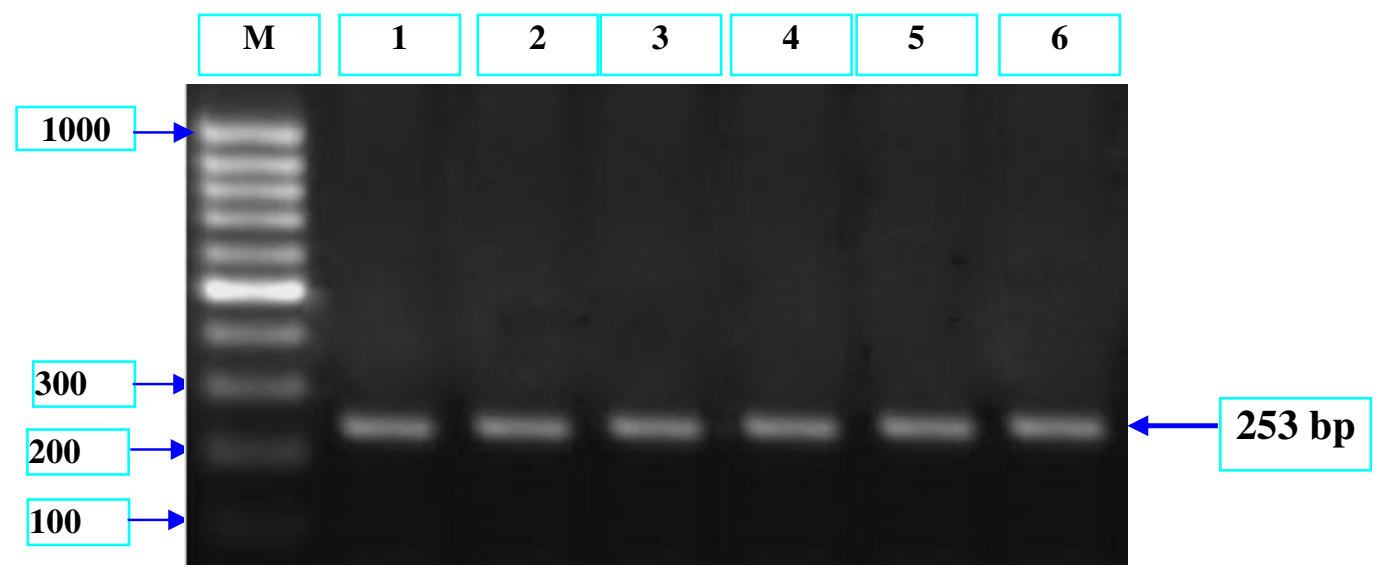

Plate 10. RT-PCR products (253 bp) of IBDV from allantoic fluids analyzed using $2 \%$ agarose gel electrophoresis. $\mathrm{M}=100$ bp DNA Marker, Lane 1= reference IBDV and Lane 2-6 = field samples of IBD 


\section{A. K. M. Rakibul Hasan}

Table 3. Serological ${ }^{*}$ and molecular diagnosis (RT-PCR) of Newcastle disease and infectious bursal disease

\begin{tabular}{|c|c|c|c|c|c|c|c|c|c|c|c|c|c|}
\hline \multirow{3}{*}{\multicolumn{2}{|c|}{ Name of the Diseases }} & \multicolumn{6}{|c|}{ Serological test } & \multicolumn{6}{|c|}{ Molecular test } \\
\hline & & \multicolumn{2}{|c|}{ Broiler } & \multicolumn{2}{|c|}{ Layer } & \multicolumn{2}{|c|}{ Total } & \multicolumn{2}{|c|}{ Broiler } & \multicolumn{2}{|c|}{ Layer } & \multicolumn{2}{|c|}{ Total } \\
\hline & & $\begin{array}{c}\text { Study } \\
\text { sample }\end{array}$ & $+\mathrm{ve}$ & $\begin{array}{c}\text { Study } \\
\text { sample }\end{array}$ & $+\mathrm{ve}$ & $\begin{array}{c}\text { Study } \\
\text { sample }\end{array}$ & $+\mathrm{ve}$ & $\begin{array}{c}\text { Study } \\
\text { sample }\end{array}$ & $+\mathrm{ve}$ & $\begin{array}{c}\text { Study } \\
\text { sample }\end{array}$ & $+\mathrm{ve}$ & $\begin{array}{c}\text { Study } \\
\text { sample }\end{array}$ & $+\mathrm{ve}$ \\
\hline \multirow{3}{*}{ ND } & Field samples & - & - & - & - & - & - & 7 & 5 & 27 & 15 & 34 & 20 \\
\hline & $\mathrm{AF}$ & 5 & 4 & 21 & 15 & 26 & 19 & 5 & 4 & 21 & 15 & 26 & 19 \\
\hline & Field samples & 11 & 10 & 6 & 5 & 17 & 15 & 11 & 10 & 6 & 5 & 17 & 15 \\
\hline IBD & $\begin{array}{c}\text { CAM + embryo } \\
\text { suspension }\end{array}$ & 8 & 7 & 3 & 3 & 11 & 10 & 8 & 7 & 3 & 3 & 11 & 10 \\
\hline
\end{tabular}

*Agar gel immunodiffusion test for IBDV and Hemagglutination Inhibition test for NDV

\section{Comparison between the clinical and laboratory diagnoses of viral diseases}

A total of 187 dead and sick birds were examined under this study, of which 34 birds were clinically diagnosed as Newcastle disease and 15 as infectious bursal diseases. All the clinically diagnosed samples were inoculated in avian embryos that results 20 virus isolation positive for NDV and 11 for IBDV. A total of 19 samples out of $26 \mathrm{NDV}$ isolates were neutralized by anti-NDV hyper-immune serum whereas, AGIDT detected 15 of 17 field samples and 10 of 11 laboratory isolates as IBDV. Finally all the samples were subjected for molecular detection method using RT-PCR. Out of 34 field samples, 26 and of the 26 NDV isolates, 19 were positive for the detection of ND viral genome by RT-PCR. In case of IBDV, 15 of 17 field samples and 10 of 11 laboratory isolates were positive by RT-PCR (Table 4). In this study, the result revealed that all the clinically diagnosed ND and IBD samples were not positive by laboratory diagnostic method (serological and molecular method) which may be other than ND or IBD. On the other hand both the serological using virus specific hyperimmune serum and molecular methods using viral genome specific primers diagnosed positively similar number of field and laboratory samples in both cases of ND and IBD which indicated higher accuracy of disease diagnosis (Lee et al., 1994; Kianizadeh, et al., 1999 and Singh, et al., 2005).

Table 4. Comparison between the clinical and laboratory diagnosis of newcastle and infectious bursal diseases

\begin{tabular}{|c|c|c|c|c|c|c|c|c|c|c|c|c|c|c|}
\hline \multirow{4}{*}{ 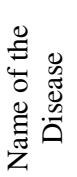 } & \multirow{4}{*}{ 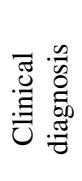 } & \multicolumn{13}{|c|}{ Laboratory diagnosis } \\
\hline & & \multirow{3}{*}{ VI } & \multicolumn{6}{|c|}{ Serological detection** } & \multicolumn{6}{|c|}{ Molecular detection (RT-PCR) } \\
\hline & & & \multicolumn{3}{|c|}{ Field samples } & \multicolumn{3}{|c|}{ Laboratory samples* } & \multicolumn{3}{|c|}{ Field samples } & \multicolumn{3}{|c|}{ Laboratory samples* } \\
\hline & & & SS & +ve & $\%$ & SS & $+\mathrm{ve}$ & $\%$ & SS & $+\mathrm{ve}$ & $\%$ & SS & +ve & $\%$ \\
\hline ND & 34 & 26 & - & - & - & 26 & 19 & 73.03 & 34 & 20 & 58.82 & 26 & 19 & 73.03 \\
\hline IBD & 17 & 11 & 17 & 15 & 88.23 & 11 & 10 & 90.90 & 17 & 15 & 88.23 & 11 & 10 & 90.90 \\
\hline
\end{tabular}

Serological detection**= Agar gel immunodiffusion test for IBDV and Hemagglutination Inhibition test for NDV, Laboratory samples*= Virus isolation positive allantoic fluid for ND and CAM+embryo suspension for IBDV, SS= Study samples, VI= Virus isolation.

Therefore, it may be concluded that serological (HI \& AGIDT) and molecular (RT-PCR) techniques which allow rapid identification of most of samples are the reliable, sensitive, specific and more accurate methods to detect the viruses for the confirmatory diagnosis of diseases.

\section{REFERENCES}

1. Alders RG, Inoune S and Katongo JC (1994). Prevelence and evaluation of Hitchner B1 and vaccine for the control of Newcastle disease in village chickens in Zambia. Preventive Veterinary Medicine 21: 125-132.

2. Alexander DJ (1997). Newcastle disease and other avian Paramyxoviridae infections. In: Calnek BW, Barnes HJ, Beard CW, McDougald LR, Saif YM (ed), Disease of poultry, 10th edn. Iowa State University Press, Ames Iowa, pp 541-570.

3. Anon (1971). Methods for examining poultry biologics and for identifying and quantifying avian pathogens. Newcastle disease, p. 66. National Academy of Science, Washington, D. C.

4. Banda A (2002). Characterization of field strains of Infectious bursal disease virus (IBDV) using molecular techniques. Dissertation (Doctor of Pholosophy). 
5. Banda A, Villegas P, El-Attrache J and Estevez C (2001). Molecular characterization of seven field isolates of infectious bursal disease virus obtained from commercial broiler chickens. Avian Disease 45(3): 620-30.

6. Banerjee M, Reed W, Fitzgerald SD and Paniger B (1994). Neurotropic, Velogenic Newcastle disease in cormorants in Michigan: pathology and virus characterization. Avian Disease 38(4): 873-8.

7. Barbezange C and Jestin V (2005). Molecular study of the quasispecies evolution of a typical pigeon paramyxovirus type 1 after serial passages in pigeons by contact. Avian pathology 34: $111-122$.

8. Beach JR (1942). Avian pneumoencephalitis. Proceeding of annual meeting in US livestock sanitary association. 46: 203-223.

9. Beard CW and Hanson RP (1984). Newcastle Disease. In: M.S. Hofstad, H.J. Barnes, B.W. Calnek, W.M. Reid and H.W. Yoder (Eds.) Diseases of Poultry 8 edn (pp 452-470).

10. Chettele NJ, Stuart JC and Wyeth PJ (1989). Outbreak of virulent infectious bursal disease East Anglia. Veterinary Records 125: 271-272.

11. ClaudiaMarin M, Villegas P, Bennet JD and Seal BS (1996). Virus characterization and sequence of the fusion protein gene cleavage site of recent Newcastle disease virus field isolates from the Southeastern United States and Puerto Rico. Avian Disease 40: 382-390.

12. Crespo R, Shivaprasad HL, Woolcock, PR. Chin R.P, Davidson-York D and Tarbell R (1999). Exotic Newcastle disease in a game chicken flock. Avian Disease. 43 (2): 349-355.

13. Eisa M and Omer EA (1984). A natural outbreak of newcastle disease in pigeons in Sudan. Veterinary Records 114: 297.

14. Gohm DS, Thur B and Hofmann MA (2000). Detection of Newcastle disease virus in organs and faeces of experimentally infected chickens using RT-PCR. Avian Pathology 29: 143-152.

15. Gupta AK, Oberoi MS and Maiti NK (2001). Detection of infectious bursal disease virus strains of varying pathogenicity under field conditions. Indian Journal of Comparative Microbiology, Immunology and Infectious diseases 22: 26-28.

16. Hernandez M, Banda A, Hernandez D, Panzera F and Perez R (2006). Detection of very virulent strains of infectious bursal disease virus (vvIBDV) in commercial broilers from Uruguay. Avian Disease 50(4): 624-31.

16. Hitchner SB (1970). The differentiation of infectious bursal disease (Gumboro) and avian nephrosis. 14th World Poult. Cong., Madrid. Abstr. Sci. Commun. Sect. II., pp. 447.

17. Islam MR (2005). A manual for the production of BAU 404 Gumboro vaccine. Submitted to the Department of Livestock Services, Dhaka, Bangladesh.

18. Islam MT and Samad MA (2004a). Clinico-pathological studies on natural and experimental infectious bursal disease in broiler chickens. Bangladesh Journal of Veterinary Medicine 2: 31-35.

19. Ismail N, Saif YM and Moorhead PD (1988). Lack of pathogenicity of five serotype 2 infectious bursal disease viruses in chickens. Avian Disease 32: 757-759.

20. Jackwood DJ, Saif YM and Hughes JH 91984). Nucleic acid and structural proteins of infectious bursal disease virus isolates belonging to serotypes I and II. Avian Disease 28: 990-1006.

21. Kant A, Koch G, Van Roozelaar DJ, Balk F and Ter Hurne A (1997). Differentiation of virulent and nonvirulent strains of Newcastle disease virus within 24 hours by polymerase chain reaction. Avian Pathology 26: 837-849.

22. Karunakaran K, Thanappapilldi M and Raghavan N (1993). Seroprevalence of Infectious Bursal Disease (IBD) in parts of Tamil Nadu, India. Comparative Microbiology, Immunology and Infectious diseases 16: 241-244.

23. Kataria RS, Tiwari AK, Butchaiah G and Kataria JM (2000). Development of probes for differentiation of infectious bursal disease virus strains of various virulence by dot-blot hybridization. Acta Virology 44: 259-263.

24. Kianizadeh AM, Ideris SMS, Kargar R, Pourbakhsh SA, Omar AR and Yusoff K (1999). Biological and Molecular Characterization of Newcastle Disease Virus Isolated from Iran. Razi Ins. Arch 50.

25. Kotani T, Ddagiri Y, Nakamura J and Horiuchi T (1987). Pathological changes of tracheal mucosa in chickens infected with lentogenic NDV. Avian Disease 31: 491-497. 


\section{A. K. M. Rakibul Hasan}

26. Lee LH, Yu SL and Shieh HK (1994). Detection of infectious bursal disease virus infection using the polymerase chain reaction. Department of Veterinary Medicine, National Chung Hsing University, Taichung, Taiwan, People's Republic of China.

27. Liu HJ, Giambrone JJ and Dormitorio T (1994). Detection of genetic variations in serotype I isolates of infectious bursal disease virus using polymerase chain reaction and restriction endonuclease analysis. Journal of Virology Methods 48: 281-291.

28. Liu X, Giambrone JJ and Dormitorio T (1998). Simplified sample processing combined with a sensitive nested polymerase chain reaction assay for detection of infectious bursal disease virus in the bursa of Fabricus. Avian Disease 42: 480-485.

29. Lukert PD and Hitchner SB (1984). Infectious BursalDisease. In: Diseases of Poultry, eds. Hofstad M. S.,H. J. Barnes, B. W. Calnek, W. M. Reid and H.W.Yoder Jr., 8 edn. Iowa State University Press,thAmes, USA, pp: 566-576.

30. Lukert PD and Saif YM (2003). Infectious Bursal Disease. In: Diseases of Poultry, $11^{\text {th }}$ edn. Y. M. Saif, H. J. Barnes., A. M. Fadly., J. R. Glisson., L. R. McDougald., and D. E. Swayne., eds. Iowa State Press, Ames, Iowa. pp. 721-738.

31. Lukert PD and Saif YM (1997). Infectious bursal disease. In: Diseases of poultry, $10^{\text {th }}$ ed. B.W.Calnek, H.J. Barnes, C.W. Bread, L.R. McDougald, and Y.M. Saif, eds. Iowa state University Press, Ames, IA. Pp. 721-738.

32. Manin TB, Shcherbakova LO, Bochkov IuA, El'nikov VV, Pchelkina,IP, Starov SK and Drygin VV 2(002). Characteristics of field isolates of Newcastle disease virus isolated in the course of outbreaks in the poultry plant in the Leningrad region in 2000: Vopr. Virusol. 47(6): 41-3.

33. Mathivanan K, Kumanan K and Nainar AM (2004). Characterization of Newcastle disease virus isolated from apparently normal guinea fowl (Numida elagridis). Veterinary Research Communications. 28: 171-177.

34. Muhammad K, Muneer A, Anwer, MS and Yaqub MT (1996). Failure of vaccines to control infectious bursal disease in commercial poultry. Pakistan Veterinary Journal 16: 119-121.

35. Nanthakumar T, Kataria RS, Tiwari AK, Butchaiah G and Kataria JM (2000). Pathotyping of Newcastle disease viruses by RT-PCR and restriction enzyme analysis. Veterinary Research Communications. 24: $275-286$.

36. Okoye JO and Shoyinka SV (19830. Newcastle disease in a vaccinated flock, which had experienced subclinical infectious bursal disease. Tropical Animal Health Production 15(4): 221-5.

37. Pazhanivel N, Balsubramaniam GA, George VT and Mohan B (2002). Study of natural outbreak of Newcastle disease in and around Namakkal. Indian Veterinary Journal 79(3): 293-294

38. Rosales AG, Villegas P, Lukert PD, Fletcher OJ and Brown J (1989). Immunosuppressive potential and pathogenicity of a recent isolate of infectious bursal disease virus in commercial broiler chickens. Avian Disease 33: 724-728.

39. Singh K, Jindal N, Gupta SL, Gupta AK and Mittal D (2005). Detection of Newcastle Disease Virus Genome from the Field Outbreaks in Poultry by Reverse Transcription - Polymerase Chain Reaction. International Journal of Poultry Science 4 (7): 472-475.

40. Spackman E, Senne DA, Bulaga LL, Myers TJ, Perdue ML, Garber LP, Lohman K, Daum LT and Suarez DL (2003). Development of Real-Time RT-PCR for the detection of avian influenza virus. Avian Disease 47:1079-1082.

41. Takase K, Baba GM, Ariyoshi R and Fujikawa H (1996). Susceptibility of chicken embryos to highly virulent infectious bursal disease virus. Journal of Veterinary Medical Science 58: 1129-1131.

42. Talha AFSM (1999). Pathology of poultry diseases occurring in Mymensingh. M.S. Thesis, Department of Pathology, Faculty of Vet. Science, BAU, Mymensingh.

43. Van den Berg TP, Gonze M and Meulemans G (1991a). Acute infectious bursal disease of poultry: isolation and characterization of a highly virulent strain. Avian Pathology 20: 133-143.

44. Wood GW, Muskett JC, Herbert CN and Thornton DH (1979). Standardization of the quantitative agar gel precipitation test for antibodies to infectious bursal disease. Journal of Biological Standards 7: 89-96.

45. Woolcock PR, Shivaprasad, HL, and Rosa MD (2008). Isolation of avian influenza virus (H10N7) from an Emu (Dromaius novaehollandiae) with Conjunctivitis and Respiratory Disease. Avian Diseases 44(3): 737744. 